\title{
Calcium Inhibition of the Action of Vasopressin on the Urinary Bladder of the Toad*
}

\author{
Martin J. Petersen $\dagger$ and Isidore S. Edelman \\ (From the Cardiovascular Research Institute and the Department of Medicine, University of \\ California School of Medicine, San Francisco, Calif.)
}

Earlier studies showed that exposure of the isolated urinary bladder of the toad to vasopressin produces striking increases in passive permeability to water and urea as well as increases in active transport of $\mathrm{Na}^{+}(1-4)$. Bentley (5) observed that raising the concentration of $\mathrm{Ca}^{++}$in the serosal bathing medium depressed the response to a $1 \mathrm{mU}$ per ml concentration of vasopressin, as measured by the flow of water along a fixed osmotic gradient. In a later study, he reported that $\mathrm{Ca}^{++}$failed to antagonize the action of vasopressin on active sodium transport (6). The nature of the antagonism was not explored further.

A detailed study of $\mathrm{Ca}^{++}$inhibition of the action of vasopressin in vitro should provide additional evidence bearing on the single site theory advanced by Koefoed-Johnson, Ussing, and Andersen on the basis of studies on anuran skin $(7,8)$. According to their hypothesis, transepithelial movement of water and small solutes is limited by a diffusion barrier and a porous barrier arranged in series. The neurohypophyseal hormones increase the pore diameter of the porous boundary, thus producing marked decreases in the resistances to the bulk flow of water and to $\mathrm{Na}^{+}$transfer, as well as significant increases in the permeability coefficients of urea and related small nonelectrolytes. Leaf and his collaborators $(3,4,9-11)$, in an extensive series of studies, also found that the pore theory can be applied to the action of vasopressin on the movement of

* Submitted for publication July 23, 1963; accepted November 21, 1963.

With the assistance of grants-in-aid from the National Heart Institute (6285), the American Heart Association, and the San Francisco Heart Association.

$\dagger$ Work done during the tenure of a research fellowship of the National Heart Institute, U. S. Public Health Service. Present address: Laboratory of Kidney and Electrolyte Metabolism, National Heart Institute, Bethesda, Md. water and urea across the toad bladder. Bentley's findings, however, suggest that the effect of vasopressin on $\mathrm{Na}^{+}$transport is not a simple consequence of increased porosity at the surface of the epithelial cells. Three possibilities are raised by these observations: $a$ ) Vasopressin may contain two active sites, one of which regulates water transport (subject to $\mathrm{Ca}^{++}$inhibition) and the other $\mathrm{Na}^{+}$transport (not subject to $\mathrm{Ca}^{++}$inhibition) ; b) $\mathrm{Na}^{+}$may enter the cell via a nonaqueous pathway that is also altered by vasopressin, while not subject to $\mathrm{Ca}^{++}$antagonism; or $c$ ) vasopressin may have a separate action on the $\mathrm{Na}^{+}$pump, and $\mathrm{Ca}^{++}$has no effect on the pump site. Because of these possibilities, we elected to explore the modifying effects of $\mathrm{Ca}^{++}$on the action of vasopressin in further detail and to examine these effects on all three parameters in the domain of vasopressin action, namely, resistance to osmotic flow of water, the permeability coefficient of urea, and the active transport of $\mathrm{Na}^{+}$.

In addition, because of the recent demonstration by Orloff and Handler (12) of a dramatic correspondence between the effects of adenosine- $3^{\prime}, 5^{\prime}$ monophosphate (cyclic AMP) and vasopressin on the movements of $\mathrm{Na}^{+}$and water across the toad bladder, and their suggestion that this nucleotide is an intermediate in the action of neurohypophyseal hormones, we also investigated the effect of an increased serosal $\mathrm{Ca}^{++}$concentration on the activity of this compound.

Our results showed: 1) $\mathrm{Ca}^{++}$antagonizes the vasopressin-induced increment in osmotic flow of water across the toad bladder at low concentrations of vasopressin; this antagonism, however, is virtually completely reversed at high concentrations of vasopressin. Increasing the $\mathrm{Ca}^{++}$concentration on the mucosal surface of the bladder is without effect on the activity of the hormone. 2) Similarly, $\mathrm{Ca}^{++}$depresses the increment in 
urea permeability induced by low concentrations of vasopressin but has a less pronounced effect at higher levels of vasopressin. 3) In contrast to urea and water, $\mathrm{Ca}^{++}$does not modify the action of vasopressin on active $\mathrm{Na}^{+}$transport. 4) The action of cyclic AMP is unaltered by raising the $\mathrm{Ca}^{++}$concentration of the serosal medium.

\section{Methods}

Bufo marinus, which had been stored at $22^{\circ} \mathrm{C}$ on soil moistened with tap water and fasted 1 to 12 weeks, was used in all experiments. After pithing the animals, the hemibladders were harvested into modified standard Ringer's solution $(\mathrm{NaCl}, 111 \mathrm{mM} ; \mathrm{KCl}, 3.0 \mathrm{mM}$; Na$\mathrm{HCO}_{3}, 2.3 \mathrm{mM} ; \mathrm{CaCl}_{2}, 2.7 \mathrm{mM}$; glucose, $5.5 \mathrm{mM}$; urea, $2.0 \mathrm{mM}$; pH, 7.8; osmolality, $233 \mathrm{mOsm}$ per L). For studies with high concentrations of $\mathrm{Ca}^{++}$, the standard solution was altered by raising $\mathrm{CaCl}_{2}$ to 10 mmoles per $\mathrm{L}$ and reducing $\mathrm{NaCl}$ to 100 mmoles per $\mathrm{L}$ to maintain constant osmolality. A single lot of commercial neurohypophyseal extract, ${ }^{1}$ assayed at 20 pressor $U$ per $\mathrm{ml}$, was used as the source of vasopressin.

The rate of osmotic flow of water was determined gravimetrically with a Mettler balance (the reproducibility of weighing a hemibladder was $\pm 10 \mathrm{mg}$ ) in 40 minute periods according to the method of Bentley (2). Hemibladders from the same toad were mounted as bags on the ends of hollow glass cannulas, filled with 2 $\mathrm{ml}$ of standard Ringer's solution which had been diluted 1:5 with distilled water and suspended in $30 \mathrm{ml}$ of aerated standard Ringer's solution. Thus, all studies were carried out at a constant osmotic difference of 185 mOsm per L. Vasopressin was added to the serosal medium of both hemibladders in identical concentrations (either 1 or $66 \mathrm{mU}$ per $\mathrm{ml}$ ), and the weight loss was determined (period 1). Both the serosal and mucosal solutions of one hemibladder were then removed and replaced with fresh Ringer's solution containing $2.7 \mathrm{mM}$ $\mathrm{Ca}^{++}$. The paired hemibladder was similarly treated except that sufficient $\mathrm{CaCl}_{2}$ was added to the serosal solution to raise the concentration of $\mathrm{Ca}^{++}$to 10 mmoles per L. The procedure was repeated after 30 minutes. The response of each hemibladder to the same concentration of vasopressin was then remeasured (period 2). This sequence provided a double control, since the response to vasopressin at high $\mathrm{Ca}^{++}$concentrations could be compared with the response in period 1 in the same hemibladder as well as with the response in the paired hemibladder in period 2.

An identical experimental protocol was used to assess the effect of $\mathrm{Ca}^{++}$on the activity of cyclic AMP. Cyclic AMP, at a final concentration of 1 mmole per $\mathrm{L}$, was substituted for vasopressin in all periods in both hemibladders.

The influence of $\mathrm{Ca}^{++}$on vasopressin augmentation

1 Parke, Davis \& Co., Detroit, Mich.

2 Schwarz Bioresearch Inc., Orangeburg, N. Y. of urea flux and $\mathrm{Na}^{+}$transport was evaluated in a separate series of experiments in which paired hemibladders were mounted as diaphragms between glass chambers and bathed in standard Ringer's solution. The rate of active $\mathrm{Na}^{+}$transport was monitored continuously by the short-circuit technique of Ussing and Zerahn (13). The short-circuit current (scc) was considered an accurate measure of the rate of active $\mathrm{Na}^{+}$transport on the basis of observations that the $\mathrm{scc}$ is equal to net $\mathrm{Na}^{+}$transport across the toad bladder under the following conditions: $a$ ) in isotonic, aerated Ringer's solution, $b$ ) in isotonic Ringer's solution during prolonged anaerobiasis, and $c$ ) in isotonic aerated Ringer's solution before and after stimulation of the current by vasopressin and by aldosterone $(4,14,15)$. After the currents achieved stable values, usually in 2 to 4 hours, $2 \mathrm{ml}$ of an isotonic solution containing sufficient $\mathrm{CaCl}_{2}$ to result in a final concentration of 10 mmoles per $\mathrm{L}$ was added to the serosal side of one hemibladder; at the same time $2 \mathrm{ml}$ of the standard Ringer's solution was added to the serosal side of the other hemibladder.

Transepithelial movement of urea was measured with urea $\mathrm{C}^{14} \cdot{ }^{3}$ Five $\mu \mathrm{c}$ of the labeled compound was added to mucosal solutions. Samples were withdrawn from the serosal solutions at 30 -minute intervals and assayed for radioactivity to determine the mucosal to serosal flux of urea. Radioassay was performed in a 2,5-diphenyloxazole (POP), 1,4-bis-2-(5-phenyloxazolyl) benzene (POPOP) system with a liquid scintillation spectrometer. ${ }^{4}$ The urea permeability coefficient, calculated according to the method of Maffly, Hays, Lamdin, and Leaf (3), was determined for two periods before the $\mathrm{Ca}^{++}$concentration of the serosal medium of the experimental hemibladder was raised, again for two periods after this change, and finally for two periods after the addition of vasopressin (final serosal concentration of 1 or $100 \mathrm{mU}$ per $\mathrm{ml}$ ).

In a series of control experiments on paired hemibladders, urea flux and $\mathrm{Na}^{+}$transport were measured in a fashion identical to that described above, but without alteration of the serosal $\mathrm{Ca}^{++}$concentration.

\section{Results}

Osmotic flow of water. The results of an experiment are detailed in Table I in order to illustrate the method of calculation. During period 1, when both hemibladders were in standard Ringer's solution containing $1 \mathrm{mU}$ per $\mathrm{ml}$ of vasopressin, the weight loss on the two sides was approximately equal. The ratio obtained by dividing the weight loss of the experimental hemibladder by the weight loss of the control hemibladder was 1.13. In period 2 the $\mathrm{Ca}^{++}$concentra-

\footnotetext{
${ }^{3}$ California Corporation for Biochemical Research, Los Angeles, Calif.

4 Packard Instrument Co., LaGrange, Ill.
} 
TABLE I

Method of calculating the effect of $\mathrm{Ca}^{++}$on vasopressin-induced increase in osmotic flow of water*

\begin{tabular}{|c|c|c|c|c|c|}
\hline \multirow{2}{*}{$\begin{array}{l}\text { Period } \\
(40 \mathrm{~min})\end{array}$} & \multicolumn{2}{|c|}{ Experimental } & \multicolumn{2}{|c|}{ Control } & \multirow{2}{*}{$\begin{array}{l}\text { Ratio } \\
\text { Experi- } \\
\text { mental: } \\
\text { control }\end{array}$} \\
\hline & $\mathrm{Ca}^{++}$ & Weight loss & $\mathrm{Ca}^{++}$ & Weight loss & \\
\hline & $m M$ & $\underset{\text { wt tissue }}{m g / m g \text { wet }}$ & $m M$ & $\begin{array}{c}m g / m g \text { wet } \\
\text { wt tissue }\end{array}$ & \\
\hline $\begin{array}{l}1 \\
2\end{array}$ & $\begin{array}{r}2.7 \\
10.0\end{array}$ & $\begin{array}{r}10.5 \\
0.2\end{array}$ & $\begin{array}{l}2.7 \\
2.7\end{array}$ & $\begin{array}{r}9.3 \\
10.7\end{array}$ & $\begin{array}{l}1.13 \\
0.02\end{array}$ \\
\hline
\end{tabular}

* In this experiment the final concentration of vasopressin was $1 \mathrm{mU}$ per $\mathrm{ml}$ (in pressor units).

tion of the serosal solution bathing the experimental hemibladder was raised to 10 mmoles per L. The loss of weight in the experimental hemibladder during this period was less than in period 1, whereas the loss of weight in the control bladder was slightly greater than in period 1 . As a consequence, the ratio of weight losses fell to 0.02 .

The effect of $\mathrm{Ca}^{++}$on vasopressin-induced osmotic flow of water is shown in Table II. The results were calculated as shown in Table I. The mean response to $1 \mathrm{mU}$ of vasopressin per $\mathrm{ml}$ of solution was depressed by 60 to $65 \%$ when $\mathrm{Ca}^{++}$ was raised from 2.7 to 10.0 mmoles per $\mathrm{L}$. At this concentration of vasopressin, the inhibitory action of $\mathrm{Ca}^{++}$was highly significant $(\mathrm{p}<0.001)$. In contrast, at a concentration of $66 \mathrm{mU}$ per ml in $10 \mathrm{mM} \mathrm{Ca}{ }^{++}$, the ratio of response was only about $8 \%$ less than unity and did not differ significantly from the control ratio $(p>0.2)$.
A separate set of nine experiments, employing a similar protocol to that described above, was performed in which the $\mathrm{Ca}^{++}$concentration was increased to 10 mmoles per $\mathrm{L}$ on the mucosal surface of the experimental hemibladder during period 2. At a vasopressin concentration of $1 \mathrm{mU}$ per $\mathrm{ml}$ and a mucosal concentration of $\mathrm{Ca}^{++}$of 0.5 mmoles per $\mathrm{L}$ in the control hemibladders and of 10 mmoles per $L$ in the experimental hemibladders, the ratio of the increments in osmotic flow was $1.15 \pm 0.18$ (mean $\pm \mathrm{SE}$ of the mean). The ratio of flows during period 1 when both hemibladders were exposed to mucosal $\mathrm{Ca}^{++}$concentrations of 0.5 mmoles per $\mathrm{L}$ was $1.12 \pm 0.12$. Therefore, changes in mucosal $\mathrm{Ca}^{++}$had no effect on the vasopressin-mediated increase in osmotic flow of water.

Table III shows the results obtained in experiments that tested the effect of raising the $\mathrm{Ca}^{++}$ concentration of the serosal medium to 10 mmoles

TABLE II

Effect of serosal $\mathrm{Ca}^{++}$on vasopressin-induced increase in osmotic flow of water

\begin{tabular}{|c|c|c|c|c|c|}
\hline & $\begin{array}{l}\text { No. of } \\
\text { exp'ts }\end{array}$ & Vasopressin & $\mathrm{Ca}^{++}$ & $\begin{array}{l}\text { Ratio } \\
\text { Experimental:control* }\end{array}$ & p \\
\hline & & $m U / m l$ & $m M$ & \multirow[b]{3}{*}{$1.14 \pm 0.20$} & \multirow{5}{*}{$<0.001$} \\
\hline Experimental & \multirow[b]{2}{*}{10} & 1 & 2.7 & & \\
\hline Control & & 1 & 2.7 & & \\
\hline Experimental & \multirow[b]{2}{*}{10} & 1 & 10.0 & \multirow[b]{2}{*}{$0.38 \pm 0.08$} & \\
\hline Control & & 1 & 2.7 & & \\
\hline Experimental & \multirow[b]{2}{*}{7} & 66 & 2.7 & \multirow[b]{2}{*}{$1.13 \pm 0.08$} & \multirow{4}{*}{$>0.2$} \\
\hline Control & & 66 & 2.7 & & \\
\hline Experimental & \multirow{2}{*}{7} & 66 & 10.0 & \multirow{2}{*}{$0.92 \pm 0.17$} & \\
\hline Control & & 66 & 2.7 & & \\
\hline
\end{tabular}

* Mean \pm SE of the mean. 
TABLE III

Effect.of serosal $\mathrm{Ca}^{++}$on cyclic AMP-induced increase in osmotic flow of water*

\begin{tabular}{|c|c|c|c|c|c|}
\hline & $\begin{array}{l}\text { No. of } \\
\text { exp'ts }\end{array}$ & Cyclic AMP & $\mathrm{Ca}^{++}$ & $\begin{array}{c}\text { Ratio } \\
\text { Experimental:control } \dagger\end{array}$ & $\mathbf{p}$ \\
\hline & & $m M$ & $m M$ & \multirow{3}{*}{$1.17 \pm 0.23$} & \multirow{5}{*}{$>0.5$} \\
\hline Experimental & \multirow{2}{*}{10} & 1 & 2.7 & & \\
\hline Control & & 1 & 2.7 & & \\
\hline Experimental & \multirow{2}{*}{10} & 1 & 10.0 & \multirow{2}{*}{$1.15 \pm 0.23$} & \\
\hline Control & & 1 & 2.7 & & \\
\hline
\end{tabular}

* Cyclic AMP, adenosine-3', 5'-monophosphate.

$\dagger$ Mean $\pm \mathrm{SE}$ of the mean.

per $\mathrm{L}$ on the action of cyclic AMP $(1 \mathrm{mM})$ on osmotic flow of water. The augmentation of the rate of osmotic flow by this nucleotide was not impaired by raising the $\mathrm{Ca}^{++}$concentration of the serosal solution.

Urea permeability. An initial series of experiments was performed in which the concentration of $\mathrm{Ca}^{++}$in the serosal medium of both hemibladders was maintained at 2.7 mmoles per L. The results are shown in the first and third rows of Table IV. The increment in the urea permeability coefficient for each hemibladder was obtained by subtracting the value obtained before addition of vasopressin from the peak value after its addition. At $1 \mathrm{mU}$ per $\mathrm{ml}$ of vasopressin the average increase in the urea permeability coefficient was $115 \times 10^{-7} \mathrm{~cm}$ per second; the pretreatment value averaged $22 \times 10^{-7} \mathrm{~cm}$ per second. At $100 \mathrm{mU}$ per $\mathrm{ml}$ of vasopressin the average increase in the urea permeability coefficient was $214 \times 10^{-7}$ $\mathrm{cm}$ per second; the pretreatment value averaged $12 \times 10^{-7} \mathrm{~cm}$ per second. The ratio of the increment in the coefficient of the experimental hemibladder to that of the control hemibladder provided an index of the effect of $\mathrm{Ca}^{++}$in the groups of experiments in which its concentration was altered. It is evident from the fact that the experimental: control (E:C) ratios approached unity, both at vasopressin concentrations of $1 \mathrm{mU}$ per $\mathrm{ml}$ and $100 \mathrm{mU}$ per $\mathrm{ml}$, that the increments in urea flux produced by the hormone were comparable in paired hemibladders when the $\mathrm{Ca}^{++}$concentration was unaltered. At a vasopressin concentration of $1 \mathrm{mU}$ per $\mathrm{ml}$, however, raising the $\mathrm{Ca}^{++}$concentration to 10 mmoles per $\mathrm{L}$ depressed this ratio by 40 to $45 \%$ (Table IV). The dif-

TABLE IV

Effect of $\mathrm{Ca}^{++}$on vasopressin-induced increase in the urea permeability coefficient

\begin{tabular}{|c|c|c|c|c|c|}
\hline & $\begin{array}{l}\text { No. of } \\
\text { exp'ts }\end{array}$ & Vasopressin & $\mathrm{Ca}^{++}$ & $\begin{array}{l}\text { Ratio } \\
\text { Experimental:control* }\end{array}$ & $\mathrm{p}$ \\
\hline & & $m U / m l$ & $m M$ & & \multirow{5}{*}{$<0.05$} \\
\hline Experimental & 10 & 1 & 2.7 & & \\
\hline Control & 10 & 1 & 2.7 & $1.04 \pm 0.18$ & \\
\hline Experimental & \multirow{2}{*}{15} & 1 & 10.0 & \multirow{2}{*}{$0.61 \pm 0.10$} & \\
\hline Control & & 1 & 2.7 & & \\
\hline Experimental & \multirow{2}{*}{9} & 100 & 2.7 & \multirow{2}{*}{$1.04 \pm 0.10$} & \multirow{4}{*}{$>0.05$} \\
\hline & & 100 & 2.7 & & \\
\hline Experimental & \multirow{2}{*}{15} & 100 & 10.0 & \multirow{2}{*}{$0.79 \pm 0.08$} & \\
\hline Control & & 100 & 2.7 & & \\
\hline
\end{tabular}

$*$ Mean \pm SE of the mean. 
ference in the ratios is statistically significant at the $5 \%$ level. In saturating concentrations of vasopressin, however, $\mathrm{Ca}^{++}$had a lesser effect. The ratios under these circumstances differed by 20 to $25 \%$, and this does not achieve statistical significance $(p>0.05)$. However, a cross-comparison of the $\mathrm{E}: \mathrm{C}$ ratios at 1 and at $100 \mathrm{mU}$ per $\mathrm{ml}$ of vasopressin does not give a statistically significant difference, suggesting that the higher concentration of vasopressin results in only a partial reversal of the $\mathrm{Ca}^{++}$effect.

Active transport of sodium. Active sodium transport was monitored in paired hemibladders by the short-circuit technique. The results of a typical experiment, illustrated in Figure 1, show the characteristic response to vasopressin in both hemibladders. Because of the high degree of variability in the ratio of the scc of the experimental to control hemibladder before the addition of vasopressin, it was necessary to use a more elaborate computation to provide a quantitative index of the effect of $\mathrm{Ca}^{++}$on the response to vasopressin. A reliable index of the tendency for the hemibladders to generate parallel scc's was obtained by calculating the ratio of the experimental to control hemibladders before and after the addition of vasopressin and then computing the quotient of the postvasopressin ratio to the pre-

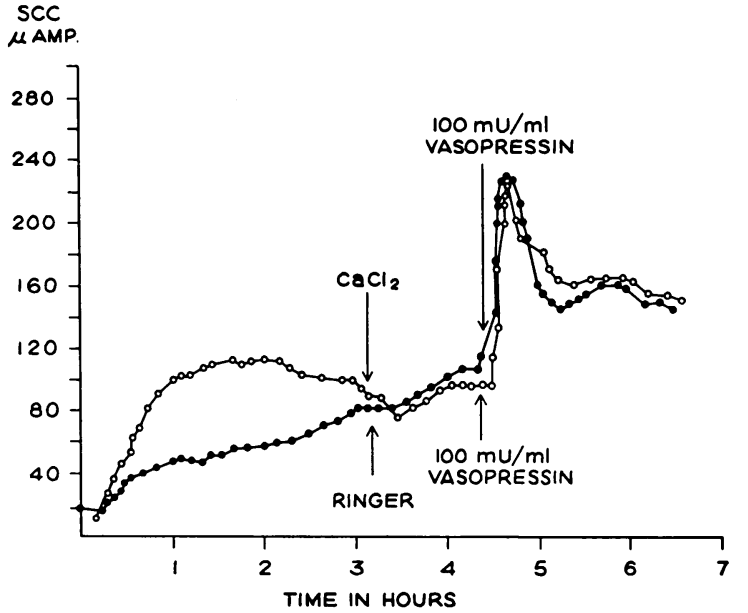

Fig. 1. EfFect of Raising the SERosal $\mathrm{CA}^{++}$CONCENTRATION FROM 2.7 TO 10.0 MMOLES PER L ON VASOPRESSININDUCED INCREASE IN THE SHORT-CIRCUIT CURRENT ( $\mathrm{sCC}$ ). At the first arrow, sufficient $\mathrm{CaCl}_{2}$ was added to the serosal medium to raise the serosal concentration to 10 mmoles per $\mathrm{L}$ in one hemibladder (solid line), and an equal volume of standard Ringer's solution was added to the other. At the second arrow, vasopressin was added to the serosal media of both hemibladders to a final concentration of $100 \mathrm{mU}$ per $\mathrm{ml}$.

vasopressin ratio. The value recorded just before the addition of hormone was taken as the prevasopressin value, and the value recorded at the very peak of the response was taken as the post-

TABLE V

Effect of $\mathrm{Ca}^{++}$on increase in short-circuit current induced by vasopressin $(1 \mathrm{mU}$ per $\mathrm{ml})$

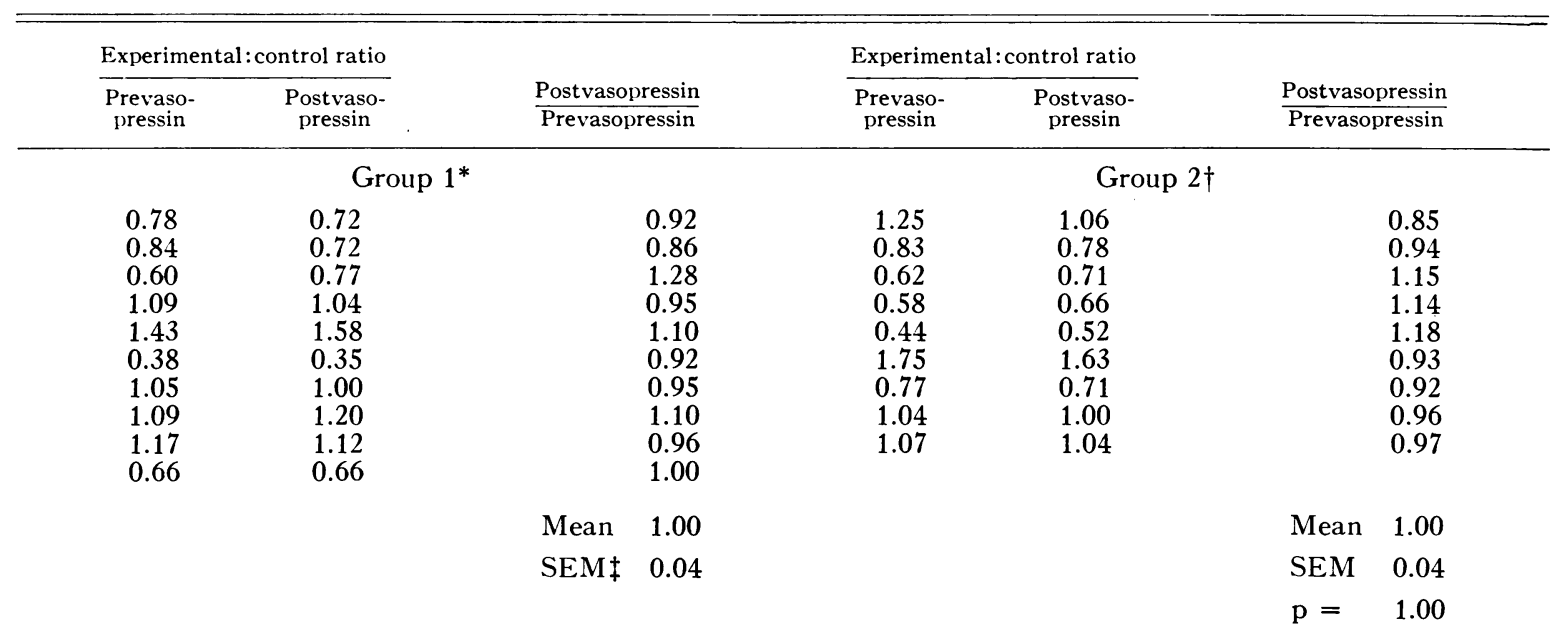

${ }^{*} \mathrm{Ca}^{++}$concentration of serosal solutions bathing both experimental and control hemibladders was $2.7 \mathrm{mmoles}$ per $\mathrm{L}$. $\dagger \mathrm{Ca}^{++}$concentration of serosal solution bathing experimental hemibladder was increased to 10 mmoles per $\mathrm{L} ; \mathrm{Ca}^{++}$ concentration of control serosal solution remained at 2.7 mmoles per L.

$\ddagger \mathrm{SE}$ of the mean. 
TABLE VI

Effect of $\mathrm{Ca}^{++}$on increase in short-circuit current induced by vasopressin (100 $\mathrm{mU}$ per $\mathrm{ml}$ )

\begin{tabular}{|c|c|c|c|c|c|c|c|}
\hline \multicolumn{2}{|c|}{ Experimental: control ratio } & \multirow{2}{*}{\multicolumn{2}{|c|}{$\frac{\text { Postvasopressin }}{\text { Prevasopressin }}$}} & \multicolumn{2}{|c|}{ Experimental:control ratio } & \multirow{2}{*}{\multicolumn{2}{|c|}{$\frac{\text { Postvasopressin }}{\text { Prevasopressin }}$}} \\
\hline $\begin{array}{c}\text { Prevaso- } \\
\text { pressin }\end{array}$ & $\begin{array}{c}\text { Postvaso- } \\
\text { pressin }\end{array}$ & & & $\begin{array}{c}\text { Prevaso- } \\
\text { pressin }\end{array}$ & $\begin{array}{c}\text { Postvaso- } \\
\text { pressin }\end{array}$ & & \\
\hline \multicolumn{4}{|c|}{ Group 1* } & \multicolumn{4}{|c|}{ Group $2 \dagger$} \\
\hline $\begin{array}{l}0.85 \\
3.47 \\
1.12 \\
0.85 \\
0.27 \\
0.64 \\
0.81 \\
0.74 \\
1.18 \\
1.00 \\
1.02\end{array}$ & $\begin{array}{l}0.76 \\
3.15 \\
1.26 \\
0.97 \\
0.23 \\
0.58 \\
0.96 \\
1.05 \\
0.99 \\
0.79 \\
1.20\end{array}$ & & $\begin{array}{l}0.89 \\
0.91 \\
1.13 \\
1.14 \\
0.85 \\
0.91 \\
1.18 \\
1.41 \\
0.84 \\
0.79 \\
1.18\end{array}$ & $\begin{array}{l}1.25 \\
1.10 \\
1.85 \\
1.32 \\
0.46 \\
1.20 \\
0.94 \\
1.54 \\
0.27 \\
0.38 \\
0.77 \\
2.80\end{array}$ & $\begin{array}{l}1.10 \\
1.19 \\
1.39 \\
1.23 \\
0.54 \\
1.28 \\
0.94 \\
1.60 \\
0.38 \\
0.53 \\
0.74 \\
2.50\end{array}$ & & $\begin{array}{l}0.88 \\
1.08 \\
0.75 \\
0.93 \\
1.17 \\
1.07 \\
1.00 \\
1.04 \\
1.40 \\
1.39 \\
0.96 \\
0.89\end{array}$ \\
\hline 1.02 & & $\begin{array}{l}\text { Mean } \\
\text { SEM } \ddagger\end{array}$ & $\begin{array}{l}1.02 \\
0.06\end{array}$ & & & $\begin{array}{l}\text { Mean } \\
\text { SEM } \\
\mathrm{p}=\end{array}$ & $\begin{array}{l}1.04 \\
0.06 \\
>0.5\end{array}$ \\
\hline
\end{tabular}

${ }^{*} \mathrm{Ca}^{++}$concentration of serosal solutions bathing both experimental and control hemibladders was $2.7 \mathrm{mmoles}$ per $\mathrm{L}$. $+\mathrm{Ca}^{++}$concentration of serosal solution bathing experimental hemibladder was increased to 10 mmoles per $\mathrm{L} ; \mathrm{Ca}^{++}$ concentration of control serosal solution remained at 2.7 mmoles per $\mathrm{L}$.

$\ddagger \mathrm{SE}$ of the mean.

vasopressin value. At $1 \mathrm{mU}$ per $\mathrm{ml}$ of vasopres$\sin$, the average increase in the scc was $91 \mu \mathrm{a}$; the pretreatment value averaged $168 \mu \mathrm{a}$. At $100 \mathrm{mU}$ per $\mathrm{ml}$ of vasopressin, the average increase in the scc was $120 \mu \mathrm{a}$; the pretreatment value averaged $143 \mu \mathrm{a}$.

Table $\mathrm{V}$ shows that at equal serosal $\mathrm{Ca}^{++}$concentrations of 2.7 mmoles per $\mathrm{L}$, the hemibladders responded proportionately to vasopressin, as indicated by an average quotient of 1.0. Raising the $\mathrm{Ca}^{++}$concentration to 10 mmoles per $\mathrm{L}$ (Table V) had no effect on the response to $1 \mathrm{mU}$ per $\mathrm{ml}$ of vasopressin, since the average quotient was also $1.0 \pm 0.04$.

TABLE VII

Effects of vasopressin at low and high concentrations on the short-circuit current (scc)

\begin{tabular}{cccc}
\hline \hline $\begin{array}{c}\text { No. of } \\
\text { exp'ts }\end{array}$ & $\begin{array}{c}\text { Vaso- } \\
\text { pressin }\end{array}$ & $\begin{array}{c}\text { Fractional rise } \\
\text { in scc*. }\end{array}$ & p \\
\hline & $m U / m l$ & & \\
53 & 1 & $0.54 \pm 0.05$ & $<0.001$ \\
71 & 100 & $0.84 \pm 0.05$ & \\
\hline
\end{tabular}

* Fractional rise $=$ scc after hormone - scc before hormone $\dagger \mathrm{Mean} \pm \mathrm{SE}$ of the mean.
In a similar set of experiments at vasopressin concentrations of $100 \mathrm{mU}$ per $\mathrm{ml}$ (Table VI), the postvasopressin to prevasopressin ratio was close to unity at equal $\mathrm{Ca}^{++}$concentrations of 2.7 mmoles per L. No change in the quotient was observed when the serosal $\mathrm{Ca}^{++}$concentration of the experimental hemibladder was raised to 10.0 mmoles per $\mathrm{L}$ (mean $\pm \mathrm{SE}$ of the mean : $1.04 \pm 0.06$ ).

Because of the possibility that calcium antagonism of vasopressin-stimulated $\mathrm{Na}^{+}$transport might be manifest only in the presence of an osmotic gradient, with its attendant cellular changes, a series of experiments was performed to examine this point. Standard Ringer's solution, diluted $1: 5$ with distilled water, was placed on the mucosal surfaces of paired hemibladders. The serosal side of the control hemibladder was bathed by standard Ringer's solution and that of the experimental hemibladder by standard Ringer's solution with $10 \mathrm{mM} \mathrm{CaCl}_{2}$ substituted for an osmotically equivalent amount of $\mathrm{NaCl}$. Short-circuit current was continuously recorded in the conventional manner. After suitable control periods during which the scc reached stable values, $1 \mathrm{mU}$ per $\mathrm{ml}$ of vasopressin was added to both hemibladders. In 12 experiments, the postvasopressin: prevasopressin ratios averaged 1.12 (SE of the 
mean, 0.06). This value was not significantly different from the theoretical value of 1.00 ( $p$, 0.2 ). Therefore, the presence of an osmotic gradient did not modify the results observed previously. No inhibition by calcium of the effect of vasopressin on $\mathrm{Na}^{+}$transport was observed.

These data confirm the earlier observations of Bentley (6) and, in addition, show that $\mathrm{Ca}^{++}$at concentrations greater than 8 mmoles per $\mathrm{L}$ does not alter the response of the scc to vasopressin either at low ( $1 \mathrm{mU}$ per $\mathrm{ml})$ or high $(100 \mathrm{mU}$ per $\mathrm{ml}$ ) concentrations. These findings in themselves, however, do not prove that $\mathrm{Ca}^{++}$dissociates the action of vasopressin on water flow from its action on active $\mathrm{Na}^{+}$transport, since it is possible that even at $1 \mathrm{mU}$ per $\mathrm{ml}$, the vasopressinresponsive element was saturated as far as the effect on $\mathrm{Na}^{+}$transport was concerned. To eliminate this objection, it was necessary to demonstrate that the increase in scc at vasopressin concentrations of $1 \mathrm{mU}$ per $\mathrm{ml}$ is measurably smaller than the increase at $100 \mathrm{mU}$ per $\mathrm{ml}$. Accordingly, the fractional rise in scc (i.e., scc at peak of response to vasopressin minus scc at base line just before the addition of vasopressin divided by the base-line value) in response to $1 \mathrm{mU}$ per $\mathrm{ml}$ and $100 \mathrm{mU}$ per $\mathrm{ml}$ was measured in separate hemibladders after the scc's had achieved stable values. The results, summarized in Table VII, indicate that at $1 \mathrm{mU}$ per $\mathrm{ml}$ of vasopressin the fractional rise in scc was $30 \%$ less than the rise at $100 \mathrm{mU}$ per $\mathrm{ml}$. The difference was significant at the $0.1 \%$ level. As indicated above, the vasopressinsensitive element with respect to urea diffusion is not saturated at a concentration of vasopressin of $1 \mathrm{mU}$ per $\mathrm{ml}$. Previous studies have also shown that raising the concentration of vasopressin from 1 to $100 \mathrm{mU}$ per $\mathrm{ml}$ produces a significantly greater effect on osmotic flow of water (16).

\section{Discussion}

An impressive body of evidence has been accumulated in support of the thesis advanced by Koefoed-Johnsen and Ussing (7) that vasopres$\sin$ accelerates the rate of osmotic flow of water across anuran skin by enlarging the cross-sectional diameter of aqueous channels that penetrate the outer-facing cell membrane of the skin. This evidence can be summarized as follows: 1 )
The probable existence of pores traversing the epithelial cell membrane of anuran skin was inferred from the observation that the unidirectional flux of water and thiourea is retarded in proportion to the net flow of water (solvent drag) (8). 2) Tracer studies indicated that vasopressininduced increases in net water flow under the impress of a fixed osmotic gradient involve an increase in hydrodynamic rather than diffusional flow of water $(7)$. These results fit the postulate that vasopressin reduces the resistance to osmotic flow and implies an effect on pores. 3) The permeability coefficient for net flow of water under an osmotic gradient (unit $=\mathrm{ml} \cdot \mathrm{cm}^{-2} \cdot \mathrm{sec}^{-1} / \mathrm{os}$ motic pressure gradient) is increased fourfold at the outer surface of the anuran skin by the addition of vasopressin (17).4) Studies on the swelling of the epithelial cells of the toad skin have shown that the equivalent pore radius of the outer surface was increased from 4.5 to 6.5 A by vasopressin as judged by the response to probing molecules of graded size (18). The experiments of Hays and Leaf (9-11) on the isolated urinary bladder of the toad gave results compatible with the pore hypothesis. They reported that the net flow of water in the presence of vasopressin is proportional to the osmotic gradient, that the epithelial cell volume is increased by vasopressin, and that the rate of tissue labeling by tritiated water placed on the mucosal side of the bladder is increased by vasopressin. These studies, as well as earlier data derived from tissue labeling with urea $\mathrm{C}^{14}$ and isotopic water by Maffly and associates (3), also indicate that vasopressin acts by altering the permeability characteristics of the mucosal surface of the bladder epithelium. In addition, Whittembury, Sugino, and Solomon (19) found that high concentrations of $\mathrm{Ca}^{++}$reduced the vasopressin-mediated increase in equivalent pore radius in slices of Necturus kidney. The finding that vasopressin is highly specific in its effects on increasing the permeability of the mucosal surface of the toad bladder to a variety of small amides has been cited in support of the Andersen-Ussing concept of a permeability barrier made up of a diffusion and a porous barrier in series, the porous barrier being subject to modification by vasopressin (10).

With these observations, it is possible to account for the depressant effect of high concentra- 
tions of $\mathrm{Ca}^{++}$on vasopressin-induced increases in osmotic flow of water and the mucosal to serosal unidirectional flux of urea by assuming that $\mathrm{Ca}^{++}$ competes with vasopressin, or an intermediate, for binding sites in the porous mucosal barrier. This explanation would account for the reversibility of the $\mathrm{Ca}^{++}$effect on both water flow and urea diffusion ( $c f$. Tables II and IV). One feature of the comparative action of vasopressin on water flow versus urea diffusion that is still open to question is the lesser effect of $\mathrm{Ca}^{++}$on urea diffusion at low concentrations of vasopressin and the failure to observe complete reversibility at high concentrations. Although our studies do not provide a satisfactory answer to this question, it is still possible to examine the mechanism of the $\mathrm{Ca}^{++}$effect further by analysis of the data on active $\mathrm{Na}^{+}$transport as measured by the short-circuit technique. Frazier, Dempsey, and Leaf (20) have confirmed that vasopressin induces proportionate increases in scc and the unidirectional mucosal to serosal flux of sodium.

In general, three possible explanations for the observed divergence in the effect of $\mathrm{Ca}^{++}$on vasopressin-induced increases in osmotic flow of water and transepithelial urea diffusion and its effect on active $\mathrm{Na}^{+}$transport are available: ${ }^{5}$ 1) The vasopressin molecule may contain two active sites, one of which exerts an effect on water and urea migration across the mucosal face of the epithelium and another which determines the action on $\mathrm{Na}^{+}$transport. In this case $\mathrm{Ca}^{++}$may reversibly bind to the determinant of the effect on water and urea movement but not to the determinant of the effect on $\mathrm{Na}^{+}$transport. 2) There may be two modes of passage across the mucosal boundary: a porous barrier modified by vasopressin to facilitate water and urea movement and a site for $\mathrm{Na}^{+}$migration that is also subject to the action of vasopressin. In this case $\mathrm{Ca}^{++}$may competitively block the access of vasopressin to the sites of water and urea transit but not to the site of $\mathrm{Na}^{+}$entry. 3) Vasopressin, or an intracellular intermediate generated by vasopressin, may have two sites of action: one on the mucosal barrier,

\footnotetext{
5 The possibility that $\mathrm{Ca}^{++}$acts at the serosal surface to alter water and urea movement without an effect on $\mathrm{Na}^{+}$movement is unlikely, since $\mathrm{Ca}^{++}$does not alter the movement of these species either in the absence of vasopressin or in the presence of cyclic AMP.
}

which determines the rate of passage of water, small amides, and, perhaps, $\mathrm{Na}^{+}$into the epithelial cells, and the other on the $\mathrm{Na}^{+}$pump postulated to be located in the serosal face of the epithelial cells. In this case $\mathrm{Ca}^{++}$may competitively block the action of vasopressin on the mucosal diffusion barrier but have no effect on the action of the $\mathrm{Na}^{+}$ pump.

The first possibility may be evaluated by comparing the affinity constants $\left(\mathrm{K}_{\mathrm{a}}\right)$ for $\mathrm{Ca}^{++}$interaction with peptide substitutents to the derived constant based on the observed effect of $\mathrm{Ca}^{++}$on the action of vasopressin on water flow. There are two relevant equations:

A) If vasopressin is divalent,

$$
\mathrm{Ca}^{++}+V^{=} \rightleftharpoons \mathrm{Ca} V
$$

then

$$
K_{a}=\left[\frac{V_{0}}{V}-1\right] \frac{1}{\mathrm{Ca}^{++}} .
$$

B) If vasopressin is univalent,

and

$$
\mathrm{Ca}^{++}+2 V^{-} \rightleftharpoons \mathrm{Ca}(V)_{2},
$$

$$
K_{a}=\left[\frac{V_{0}}{V^{2}}-\frac{1}{V}\right] \frac{1}{\mathrm{Ca}^{++}} .
$$

$V_{o}$ denotes the total vasopressin concentration; $V$, the free vasopressin concentration; and $\mathrm{Ca}^{++}$, the free ion concentration. In the first instance (Equation 1) $K_{a}$ would have to be $>10^{2}$ to explain the observed magnitude of inhibition, and in the second, $K_{a}$ would have to be $>2 \times 10^{2}$. From model systems it has been inferred that $K_{a}$ for $\mathrm{Ca}^{++}: \mathrm{COO}^{-}$is $10^{0.5}$, for $\mathrm{Ca}^{++}: \mathrm{NH}$ it is $10^{0.2}$, and for $\mathrm{Ca}^{++}: \mathrm{RS}^{-}$it is $<10^{0.2}(21)$. It appears unlikely, therefore, that $\mathrm{Ca}^{++}$binding to vasopressin accounts for a significant part of the observed effect on water flow.

The second possible explanation for the divergent effects of $\mathrm{Ca}^{++}$is based on the postulate of Frazier and associates (20) that $\mathrm{Na}^{+}$crosses the mucosal face of the bladder epithelial cells via a saturable pathway rather than by simple diffusion through water-filled pores. The evidence quoted in support of this postulate is as follows: a rise in mucosal $\mathrm{Na}^{+}$concentration up to $60 \mathrm{mEq}$ per $\mathrm{L}$ evoked an increase in active $\mathrm{Na}^{+}$transport and in the $\mathrm{Na}^{+}$content of the bladder wall, 
whereas a further rise from 60 to $114 \mathrm{mEq}$ per $\mathrm{L}$ failed to increase either transport or the intracellular concentration of $\mathrm{Na}^{+}$. A critical element in this argument is the inference that saturation of the $\mathrm{Na}^{+}$transport system ${ }^{6}$ occurred at a mucosal concentration of $\mathrm{Na}^{+}$of $60 \mathrm{mEq}$ per $\mathrm{L}$. In a single experiment, Frazier and co-workers (20) found that the scc reached a limiting value when mucosal $\mathrm{Na}^{+}$was raised from 20 to 114 $\mathrm{mEq}$ per $\mathrm{L}$. In an additional set of 10 paired experiments, no statistically significant increase in scc was found when mucosal $\mathrm{Na}^{+}$was raised from 60 to $114 \mathrm{mEq}$ per L (22). It is possible, therefore, that $\mathrm{Ca}^{++}$blocks the action of vasopres$\sin$ at the site of water and urea transit across the mucosal cell membrane but does not alter hormonal action on $\mathrm{Na}^{+}$entry via a saturable path. The recent studies of Curran, Herrera, and Flanigan $(23,24)$ also provide support for this interpretation. They inferred from tracer-kinetic studies that vasopressin increases the rate of active transport of $\mathrm{Na}^{+}$by increasing the rate of $\mathrm{Na}^{+}$entry through the outer cell membrane of the frog skin. Curran and associates (24) also concluded that vasopressin has no effect on the active transport step located in the inner cell membrane. $^{7}$ If the locus of action of $\mathrm{Ca}^{++}$were at the site of production of an intermediate (e.g., cyclic AMP), then all three effects (i.e., $\mathrm{Na}^{+}$ transport, urea diffusion, and water flow) should be coordinated. If the site of action of $\mathrm{Ca}^{++}$were at the outer or mucosal cell membrane, then the same effect should be apparent on the action of the intermediates of vasopressin as on vasopressin. Since $\mathrm{Ca}^{++}$does not block all three of the responses evoked by vasopressin and also has no effect on cyclic-AMP mediated increases in osmotic flow of water, neither of these explanations

\footnotetext{
${ }^{6}$ The $\mathrm{Na}^{+}$transport system is assumed to include both the diffusion step at the mucosal surface and the extrusion mechanism at the serosal surface of the epithelial cells.

7 Frazier and Hammer (25) recently reported that vasopressin significantly increases the rate of loss of $\mathrm{Na}^{24}$ across the mucosal boundary but has no effect on efflux across the serosal boundary of the toad bladder prelabeled with $\mathrm{Na}^{24}$. With the assumption of a common cellular pool of $\mathrm{Na}^{+}$as a basis, they concluded that the action of vasopressin on $\mathrm{Na}^{+}$transport is the result solely of an increase in the permeability to $\mathrm{Na}^{+}$of the mucosal boundary.
}

is acceptable. The action of $\mathrm{Ca}^{++}$, therefore, implies that either vasopressin exerts its effects directly on the mucosal cell membrane on two processes (i.e., entry of water and $\mathrm{Na}^{+}$) or that if there is an intermediate, the intermediate acts at both the mucosal site of entry of water and at the serosal cell membrane site of active transport of $\mathrm{Na}^{+}$. We feel that the evidence presented by Frazier and associates (20) and by Curran and associates (24) does not exclude the latter possibility. In the study by Frazier and associates (20), the intracellular (epithelial) concentration of $\mathrm{Na}^{+}$was calculated from radiosodium dilution, an indirect procedure that has not been verified by an independent method. The tracer-kinetic studies of Curran and associates (24) are based on a number of assumptions, some of which have not been checked directly as yet. Accordingly we have elected to consider the third possible explanation, namely, that vasopressin has two separate sites of action, in some detail.

The third possible explanation is based, in part, on the evidence presented by Orloff and Handler (12) that vasopressin produces its effects by regulating the rate of production of cyclic AMP. These authors showed that cyclic AMP mimics the effects of vasopressin on osmotic flow of water and on the scc across the toad bladder. In addition, both cyclic AMP and vasopressin increase phosphorylase activity in the toad bladder (26). Brown, Clarke, Roux, and Sherman (27) have recently demonstrated stimulation by vasopressin of cyclic AMP production in homogenates of dog kidneys. Since active $\mathrm{Na}^{+}$transport is metabolically dependent (14) and since exogenous substrates (e.g., glucose, pyruvate, lactate, beta hydroxybutyrate) augment the rate of active $\mathrm{Na}^{+}$ transport after prolonged in vitro incubation (28), it is conceivable that vasopressin may modify the activity of the $\mathrm{Na}^{+}$pump via effects on the intracellular supply of substrate. Evidence compatible with the possibility of a direct action of vasopressin on the $\mathrm{Na}^{+}$pump has been reported by Goodfriend and Kirkpatrick (29), who found that vasopressin increased the rate of oxidation of glucose and pyruvate by the isolated toad bladder in $\mathrm{Na}^{+}$-free media. In this instance the demonstration of an effect of the hormone on cellular metabolism obviously could not be related to an increase in the intracellular pool of 


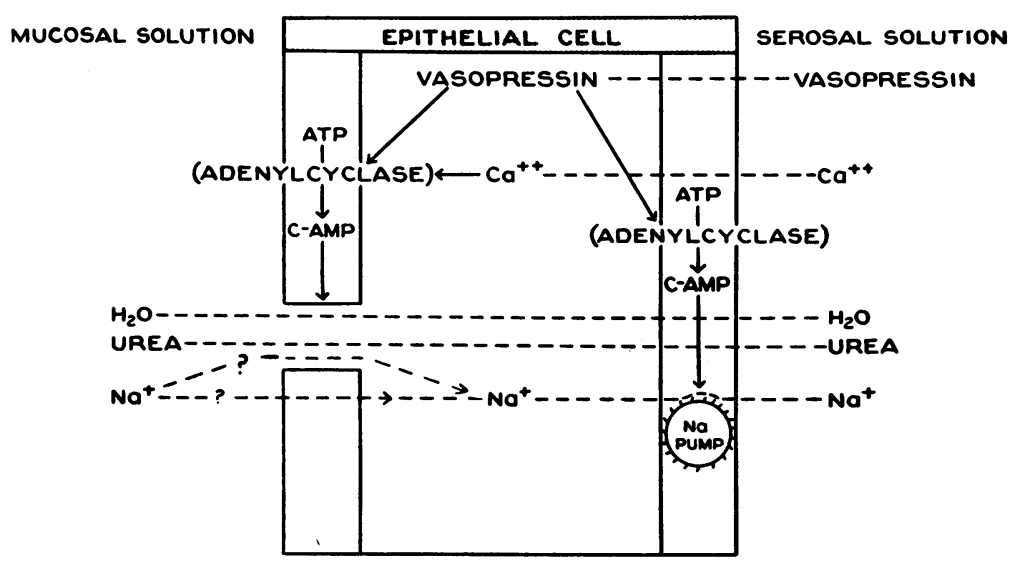

Fig. 2. Schematic Representation of the hypothesis of DUAL Sites OF ACTION OF VASOPRESSIN VIA CONTROL OF THE RATE OF FORMATION OF CyCLIC AMP. Cyclic AMP (adenosine- $3^{\prime}, 5^{\prime}$-monophosphate) is assumed to be generated and to act at two loci, at the mucosal border which controls water and urea flux and at the serosal border which controls $\mathrm{Na}^{+}$flux. $\mathrm{Ca}^{++}$is assumed to compete with vasopressin only at the mucosal site of generation of cyclic AMP.

$\mathrm{Na}^{+}$. Although these observations indicate the possibility of a direct action on the pump, definitive evidence for such an effect is still lacking. Moreover, a separate effect of vasopressin on the rate of mucosal entry of $\mathrm{Na}^{+}$may dominate any action on the pump.

However, if vasopressin exerts its effects through the agency of cyclic AMP, it becomes necessary to postulate local rather than cytoplasmic release of this nucleotide on exposure to vasopressin. Davoren and Sutherland (30) have shown that the cyclic AMP-generating system is bound to the membranous component of cells. Since $\mathrm{Ca}^{++}$does not block the action of cyclic AMP on water flow, the discrepancy in the effect of $\mathrm{Ca}^{++}$ on vasopressin-induced movements of water and $\mathrm{Na}^{+}$could not be explained by a vasopressin catalyzed production and release of cyclic AMP at a single site in the cell. A possible hypothesis of hormone- $\mathrm{Ca}^{++}$interaction is depicted in Figure 2.

In essence, the hypothesis shown in Figure 2 suggests that the initial step in the modification of the mucosal barrier to water and urea, and perhaps to $\mathrm{Na}^{+}$, is the attachment of vasopressin to a finite set of receptor sites. The same sites are assumed to be capable of binding $\mathrm{Ca}^{++}$, leading to competitive inhibition of the antidiuretic action of the hormone (see Table II). Consequent to hormonal attachment $\mathrm{Ca}^{++}$is displaced from the receptor sites, and the production of cyclic AMP ensues. The pore geometry of the mucosal membrane is then altered by an as yet undefined sequence of events fostered by cyclic AMP. Dicker and Eggleton (31) and Thorn (32) found an inverse relationship between the rate of $\mathrm{Ca}^{++}$excretion in the urine and volume flow during antidiuresis induced by posterior pituitary extracts. A second set of vasopressin receptor sites in the vicinity of the $\mathrm{Na}^{+}$pump may be a second locus for vasopressin generation of cyclic AMP, which is independent of the influence of $\mathrm{Ca}^{++}$. This proposal assumes that both vasopressin and $\mathrm{Ca}^{++}$gain access to the intracellular space of the epithelial cells of the bladder through the serosal surface; evidence is not presently available to evaluate the validity of this assumption.

\section{Summary}

At low concentrations of vasopressin $(1 \mathrm{mU}$ per $\mathrm{ml}$ ) a rise in the $\mathrm{Ca}^{++}$concentration from 2.7 to 10 mmoles per $\mathrm{L}$ depressed the hormonally induced increase in the flow of water at a fixed osmotic gradient by $65 \%$. The $\mathrm{Ca}^{++}$effect was completely reversed by increasing the vasopressin concentration to $66 \mathrm{mU}$ per $\mathrm{ml}$. A rise in $\mathrm{Ca}^{++}$ concentration to 10 mmoles per $\mathrm{L}$ also depressed the vasopressin-mediated increase in the urea 
permeability coefficient by $45 \%$ at low concentrations of vasopressin $(1 \mathrm{mU}$ per $\mathrm{ml})$. In the presence of high concentrations of vasopressin ( $100 \mathrm{mU}$ per $\mathrm{ml}$ ), a rise in $\mathrm{Ca}^{++}$concentration to 10 mmoles per $\mathrm{L}$ produced a lesser depression in the hormonal effect on urea diffusion that was not statistically significant. In contrast to the effects on water and urea, raising the concentration of $\mathrm{Ca}^{++}$had no influence on the action of vasopressin on active $\mathrm{Na}^{+}$transport. The ability of $\mathrm{Ca}^{++}$to dissociate the effects of vasopressin on water and urea from the effect on $\mathrm{Na}^{+}$transport implies a divergence in the action of the hormone that requires a modification of the unitary hypothesis. Two alternative possible explanations have been presented, taking into account the absence of an effect of $\mathrm{Ca}^{++}$on the action of adenosine- $3^{\prime}, 5^{\prime}$-monophosphate (cyclic AMP) on osmotic flow of water.

\section{Acknowledgment}

Mr. Glenn Downes and Miss Ella Highland provided able technical assistance throughout this study.

\section{References}

1. Ewer, R. F. The effect of pituitrin on fluid distribution in Bufo regularis Reuss. J. exp. Biol. 1952, 29, 173.

2. Bentley, P. J. The effects of neurohypophysial extracts on water transfer across the wall of the isolated urinary bladder of the toad Bufo marimus. J. Endocr. 1958, 17, 201.

3. Maffly, R. H., R. M. Hays, E. Lamdin, and A. Leaf. The effect of neurohypophyseal hormones on the permeability of the toad bladder to urea. J. clin. Invest. 1960, 39, 630.

4. Leaf, A., and E. Dempsey. Some effects of mammalian neurohypophyseal hormones on metabolism and active transport of sodium by the isolated toad bladder. J. biol. Chem. 1960, 235, 2160.

5. Bentley, P. J. The effects of ionic changes on water transfer across the isolated urinary bladder of the toad Bufo marinus. J. Endocr. 1959, 18, 327.

6. Bentley, P. J. The effects of vasopressin on the short-circuit current across the wall of the isolated bladder of the toad, Bufo marinus. J. Endocr. $1960,21,161$.

7. Koefoed-Johnsen, V., and H. H. Ussing. The contributions of diffusion and flow to the passage of $\mathrm{D}_{2} \mathrm{O}$ through living membranes. Effect of neurohypophyseal hormone on isolated anuran skin. Acta physiol. scand. 1953, 28, 60.

8. Andersen, B., and H. H. Ussing. Solvent drag on non-electrolytes during osmotic flow through iso- lated toad skin and its response to antidiuretic hormone. Acta physiol. scand. 1957, 39, 228.

9. Hays, R. M., and A. Leaf. Studies on the movement of water through the isolated toad bladder and its modification by vasopressin. J. gen. Physiol. 1962, 45, 905.

10. Leaf, A., and R. M. Hays. Permeability of the isolated toad bladder to solutes and its modification by vasopressin. J. gen. Physiol. 1962, 45, 921.

11. Hays, R. M., and A. Leaf. The state of water in the isolated toad bladder in the presence and absence of vasopressin. J. gen. Physiol. 1962, 45, 933.

12. Orloff, J., and J. S. Handler. The similarity of effects of vasopressin, adenosine- $3^{\prime}, 5^{\prime}$-phosphate (cyclic AMP) and theophylline on the toad bladder. J. clin. Invest. 1962, 41, 702.

13. Ussing, H. H., and K. Zerahn. Active transport of sodium as the source of electric current in the short-circuited isolated frog skin. Acta physiol. scand. 1951, 23, 110.

14. Leaf, A., J. Anderson, and L. B. Page. Active sodium transport by the isolated toad bladder. J. gen. Physiol. 1958, 41, 657.

15. Crabbé, J. Stimulation of active sodium transport by the isolated toad bladder with aldosterone in vitro. J. clin. Invest. 1961, 40, 2103.

16. Edelman, I. S., and M. J. Petersen. A kinetic analysis of the antidiuretic action of vasopressin (abstract). J. clin. Invest. 1962, 41, 1356.

17. MacRobbie, E. A. C., and H. H. Ussing. Osmotic behaviour of the epithelial cells of frog skin. Acta physiol. scand. 1961, 53, 348.

18. Whittembury, G. Action of antidiuretic hormone on the equivalent pore radius at both surfaces of the epithelium of the isolated toad skin. J. gen. Physiol. 1962, 46, 117.

19. Whittembury, G., N. Sugino, and A. K. Solomon. Effect of antidiuretic hormone and calcium on the equivalent pore radius of kidney slices from Necturus. Nature (Lond.) 1960, 187, 699.

20. Frazier, H. S., E. F. Dempsey, and A. Leaf. Movement of sodium across the mucosal surface of the isolated toad bladder and its modification by vasopressin. J. gen. Physiol. 1962, 45, 529.

21. Gurd, F. R. N., and P. E. Wilcox. Complex formation between metallic cations and proteins, peptides, and amino acids. Advanc. Protein Chem. $1956,11,311$.

22. Leaf, A. Unpublished observations.

23. Herrera, F. C., and P. F. Curran. The effect of Ca and antidiuretic hormone on $\mathrm{Na}$ transport across frog skin. I. Examination of interrelationships between $\mathrm{Ca}$ and hormone. J. gen. Physiol. 1963, 46, 999.

24. Curran, P. F., F. C. Herrera, and W. J. Flanigan. The effect of $\mathrm{Ca}$ and antidiuretic hormone on $\mathrm{Na}$ transport across frog skin. II. Sites and mechanisms of action. J. gen. Physiol. 1963, 46, 1011. 
25. Frazier, H. S., and E. I. Hammer. Efflux of sodium from isolated toad bladder. Amer. J. Physiol. 1963, 205. 718.

26. Handler, J. S., and J. Orloff. Activation of phosphorylase in toad bladder and mammalian kidney by vasopressin. Fed. Proc. 1963, 22, 541.

27. Brown, E., D. L. Clarke, V. Roux, and G. H. Sherman. The stimulation of adenosine $3^{\prime}, 5^{\prime}$-monophosphate production by antidiuretic factors. J. biol. Chem. 1963, 238, 852.

28. Maffly, R. H., and I. S. Edelman. The coupling of the short-circuit current to metabolism in the urinary bladder of the toad. J. gen. Physiol. 1963, 46, 733 .
29. Goodfriend, T., and J. Kirkpatrick. Effects of neurohypophysial hormones on oxidative metabolism of the toad bladder, in vitro. Endocrinology 1963, 72, 742.

30. Davoren, P. R., and E. W. Sutherland. The cellular location of adenyl cyclase in the pigeon erythrocyte. J. biol. Chem. 1963, 238, 3016.

31. Dicker, S. E., and M. G. Eggleton. Renal excretion of hyaluronidase and calcium in man during the antidiuretic action of vasopressins and some analogues. J. Physiol. (Lond.) 1961, 157, 351.

32. Thorn, N. A. Correlation between antidiuretic hormone effect and changes in renal excretion of calcium in rats and dogs. Acta endocr. (Kbh.) 1961, 38, 563.

\section{ANNOUNCEMENT OF MEETINGS}

The American Federation for Clinical Research will hold its Twenty-first Annual Meeting in Atlantic City, N. J., at the Casino Theater on the Steel Pier on Sunday, May 3, 1964, at 9:00 a.m. Joint sectional meetings with The American Society for Clinical Investigation will be held on Sunday afternoon at Chalfonte-Haddon Hall, and additional meetings sponsored by The American Federation for Clinical Research will be held on Sunday evening.

The American Society for Clinical Investigation, Inc., will hold its Fifty-sixth Annual Meeting in Atlantic City, N. J., on Monday, May 4, at 9:00 a.m., at the Casino Theater on the Steel Pier, and in simultaneous programs with The American Federation for Clinical Research on Sunday afternoon, May 3, in Chalfonte-Haddon Hall.

The Association of American Physicians will hold its Seventyseventh Annual Meeting in Atlantic City, N. J., at the Casino Theater on the Steel Pier on Tuesday, May 5, at 9:30 a.m., and in the Vernon Room, Chalfonte-Haddon Hall, on Wednesday, May 6, at 9:30 a.m. 